\title{
Article \\ Antimicrobial Activity of Ohelo Berry (Vaccinium calycinum) Juice against Listeria monocytogenes and Its Potential for Milk Preservation
}

\author{
Biyu Wu ${ }^{1}$, Xiaohan Liu ${ }^{1}$, Stuart T. Nakamoto ${ }^{1}$ (D), Marisa Wall ${ }^{2}$ and Yong Li ${ }^{1, *(D)}$ \\ 1 Department of Human Nutrition, Food and Animal Sciences, University of Hawaii at Manoa, \\ 1955 East West Road, Agricultural Sciences Building 216, Honolulu, HI 96822, USA; biyu@hawaii.edu (B.W.); \\ felxh6005@mail.scut.edu.cn (X.L.); snakamo@hawaii.edu (S.T.N.) \\ 2 Daniel K. Inouye U.S. Pacific Basin Agricultural Research Center, 64 Nowelo Street, Hilo, HI 96720, USA; \\ marisa.wall@usda.gov \\ * Correspondence: liyong@hawaii.edu; Tel.: +1-808-956-6408; Fax: +1-808-956-4024
}

check for updates

Citation: Wu, B.; Liu, X.; Nakamoto, S.T.; Wall, M.; Li, Y. Antimicrobial Activity of Ohelo Berry (Vaccinium calycinum) Juice against Listeria monocytogenes and Its Potential for Milk Preservation. Microorganisms 2022, 10, 548. https://doi.org/ $10.3390 /$ microorganisms 10030548

Academic Editor: Elena

González-Fandos

Received: 30 January 2022

Accepted: 28 February 2022

Published: 2 March 2022

Publisher's Note: MDPI stays neutral with regard to jurisdictional claims in published maps and institutional affiliations.

Copyright: (C) 2022 by the authors. Licensee MDPI, Basel, Switzerland. This article is an open access article distributed under the terms and conditions of the Creative Commons Attribution (CC BY) license (https:// creativecommons.org/licenses/by/ $4.0 /)$.

\begin{abstract}
Listeria monocytogenes is a foodborne pathogen and causes illnesses with a high mortality rate in susceptible populations. Several dairy-related outbreaks have been attributed to contamination by L. monocytogenes, which requires antimicrobial interventions to enhance the safety of these products. This study aimed to determine the antimicrobial activity of the ohelo berry (Vaccinium calycinum), a Hawaiian wild relative of cranberry, against L. monocytogenes in culture media and milk products. The effect of ohelo berry juice at its sub-inhibitory concentrations on the physicochemical properties, biofilm formation, and gene expression of L. monocytogenes was also investigated. The minimum inhibitory concentration of ohelo berry juice against L. monocytogenes was $12.5 \%$. The sub-inhibitory concentration of ohelo berry juice (6.25\%) significantly increased the auto-aggregation and decreased the hydrophobicity, swimming motility, swarming motility, and biofilm formation capability of $L$. monocytogenes. The relative expression of genes for motility $(f l a A)$, biofilm formation and disinfectant resistance $(\operatorname{sig} B)$, invasion (iap), listeriolysin $(h l y)$, and phospholipase (plcA) was significantly downregulated in L. monocytogenes treated by the $6.25 \%$ juice. L. monocytogenes was significantly inhibited in whole and skim milk supplemented with $50 \%$ ohelo berry juice, regardless of the fat content. These findings highlight the potential of ohelo berry as a natural preservative and functional food to prevent L. monocytogenes infection.
\end{abstract}

Keywords: ohelo berry; polyphenols; antimicrobial effect; Listeria monocytogenes; physicochemical properties; biofilm formation; gene expression; milk preservation

\section{Introduction}

Foodborne illness outbreaks not only pose a serious threat to public health but also lead to substantial economic losses for society. Listeria monocytogenes is a dangerous foodborne pathogen and can cause a severe disease named listeriosis, with a high mortality rate in susceptible populations. The Centers for Disease Control and Prevention (CDC) estimates that 1600 people have listeriosis, with around 260 deaths annually in the United States [1]. L. monocytogenes is a rod-shaped, gram-positive bacterium. It is capable of adapting to and surviving under adverse conditions, such as low temperature, low $\mathrm{pH}$, and high salt concentrations [2]. L. monocytogenes is ubiquitously present in the environment and can be found in soil, wastewater, vegetation, wild animals, livestock, etc. [3].

It was recently reported that more than $75 \%$ of L. monocytogenes outbreaks were linked to contaminated dairy products and fruits between 2015 and 2019 [4]. Moreover, the consumption of soft cheese made from unpasteurized milk or under unsanitary conditions was recognized as a potentially serious risk, especially to pregnant women and persons with weak immune systems [4]. Control of L. monocytogenes in food production remains a great 
challenge. Therefore, effective antimicrobial approaches for preventing food contamination or the occurrence of listeriosis are urgently needed.

Nowadays, consumers tend to choose more natural, healthy, and safe food [5] because inappropriate use of antimicrobial agents in food production might result in undesirable residues in food and the emergence of antimicrobial-resistant microorganisms [6]. Moreover, consuming synthetic food preservatives may cause health concerns, including potential side effects and increased cancer risks [7]. Thus, the use of natural antimicrobials in food preservation has attracted increasing attention from scientists, food manufacturers, and consumers [6].

Phytochemicals, especially polyphenolic compounds, have bioactive functions. Studies have also demonstrated that polyphenolic compounds in berries hold antimicrobial properties against various pathogens [8-11]. Additionally, the phytochemicals extracted from fruits have been proven to exhibit multiple effects on human health. The antioxidant activity of polyphenols provides them with functions such as anti-inflammation, anti-tumor, prevention of cardiovascular diseases, and delaying aging [12,13].

Cranberry (Vaccinium macrocarpon) was found to have the highest phenolic contents among the 20 common fruits in America [14] and exhibited strong antimicrobial activities against common foodborne pathogenic bacteria $[11,12,15]$. Ohelo berry is a wild relative of cranberry and grows in Hawaii only. It typically grows at elevations between 640 and $3700 \mathrm{~m}$ on disturbed volcanic sites on the islands of Maui and Hawai'i [16]. Residents usually gather ripened ohelo berries to make jam, jelly, and other foods between August and September [17]. The two most common species of ohelo berry are low-growing Vaccinium reticulatum and highbush Vaccinium calycinum [17]. V. calycinum contains a higher level of phytochemicals than $V$. reticulatum, and the total phenolic content of $V$. calycinum is seven times that of cranberry [18].

To date, there have been no reports on the antimicrobial properties of ohelo berry. This study aimed to measure the phytochemical contents of ohelo berry juice and determine its antimicrobial activities. Physicochemical properties and biofilm formation capability of $L$. monocytogenes treated with sublethal concentrations of ohelo berry juice were evaluated. Efforts were also made to investigate the influence of ohelo berry juice on the gene expression of L. monocytogenes. The potential of ohelo berry juice as a food preservative was explored in whole milk and skim milk with L. monocytogenes.

\section{Materials and Methods}

\subsection{Ohelo Berry Juice Preparation}

Ohelo berries (V. calycinum) were harvested from Hawai'i Island and stored at $-80^{\circ} \mathrm{C}$. For the following analysis, thawed ohelo berries were squeezed and filtered to obtain juice. The juice was filter-sterilized using a sterile syringe filter with $0.2 \mu \mathrm{m}$ polyethersulfone membrane (VWR) before all experiments of analyzing its antimicrobial activities were performed.

\subsection{Chemical Analysis of Ohelo Berry Juice}

\subsubsection{Quantification of Sugar and Organic Acids in Ohelo Berry Juice}

Ohelo berry juice was analyzed for the ratio of ${ }^{\circ} \mathrm{Bx}$ to titratable organic acids. The $\mathrm{pH}$ of the sample was measured using a $\mathrm{pH}$ meter (Oaklon). A refractometer (Bio-Rad, iMark) was used to quantify soluble sugar solids. The concentration of organic acids in citric acid equivalents was determined by titration with $0.1 \mathrm{M} \mathrm{NaOH}$ [19].

\subsubsection{Total Phenolic Concentration}

The total phenolics in ohelo berry juice were measured by the Folin Ciocalteu method [20]. Gallic acid stock solution was prepared by dissolving $0.5 \mathrm{~g}$ of gallic acid monohydrate (Sigma, St. Louis, MO, USA) in $10 \mathrm{~mL}$ of ethanol and then diluting to $100 \mathrm{~mL}$ with distilled water $(5 \mathrm{mg} / \mathrm{mL})$. Various concentrations of gallic acid solutions $(25,50,100,250$, and $500 \mu \mathrm{g} / \mathrm{mL}$ ) were prepared from stock as gallic acid calibration standards. A volume 
of $30 \mu \mathrm{L}$ of distilled water (control), gallic acid calibration standards, and diluted ohelo berry juice were pipetted separately into wells of a 96-well plate (Costar, Somerville, MA, USA). Then, $210 \mu \mathrm{L}$ of water, $15 \mu \mathrm{L}$ of Folin Ciocalteu reagent (EMD Millipore Corporation, Merck KGaA, Darmstadt, Germany), and $45 \mu \mathrm{L}$ of sodium carbonate solution were added sequentially into each well. The plate was incubated in the dark at room temperature for $2 \mathrm{~h}$. The absorbance was measured at $765 \mathrm{~nm}$ using a spectrophotometer (Bio-Rad, iMark, Hercules, CA, USA). After that, a standard curve was created from the readings of gallic acid standards. All the experiments were carried out in triplicates, and the average absorbance values obtained at different concentrations of gallic acid solution were used to plot the calibration curve. The concentration of phenolic compounds in ohelo berry juice was calculated using the standard curve and reported in gallic acid equivalents (GAE).

\subsubsection{Anthocyanin Concentration}

The concentration of anthocyanins in ohelo berry juice was determined using the $\mathrm{pH}$ differential method and reported in equivalents of cyanidin-3-glucoside [21]. Two buffers were prepared for this test. The $\mathrm{pH} 1.0$ buffer is $0.025 \mathrm{M}$ of potassium chloride, and the $\mathrm{pH} 4.5$ buffer is $0.4 \mathrm{M}$ of sodium acetate. The sample was diluted with the two buffers separately. Ohelo berry juice was diluted with $\mathrm{pH} 1.0$ buffer until the absorbance at $520 \mathrm{~nm}$ was within the linear range of the spectrophotometer. Furthermore, the samples were diluted at least 5 -fold with the buffers so that the buffering capacity of the reagents was not exceeded. The same dilution for $\mathrm{pH} 1.0$ buffer was used for $\mathrm{pH} 4.5$ buffer and followed by measuring absorbance at both 520 and $700 \mathrm{~nm}$ within $30 \mathrm{~min}$ of the samples being prepared, with a blank well filled with distilled water as control. The anthocyanin content was calculated according to the equation described by Lee et al. [21].

\subsection{Bacterial Strain and Growth Conditions}

L. monocytogenes F2365 was used for analyzing the antimicrobial activities of ohelo berry juice. The strain was stored at $-80^{\circ} \mathrm{C}$ as frozen stock culture. L. monocytogenes was streaked on modified Oxford agar (MOX, BD, Franklin Lakes, NJ, USA) and then grown in tryptic soy broth (TSB, BD, Franklin Lakes, NJ, USA) at $37^{\circ} \mathrm{C}$ for $24 \mathrm{~h}$ before being used in the following tests.

\subsection{Determination of the Minimum Inhibitory Concentration (MIC) and Minimum Bactericidal Concentrations (MBC) of Ohelo Berry Juice}

The antimicrobial efficacy of ohelo berry juice was determined by the standard methods of Clinical and Laboratory Standards Institute by evaluating the growth of microorganisms in microbiological broth [22]. The L. monocytogenes culture was 10-fold serially diluted to approximately $6 \log \mathrm{CFU} / \mathrm{mL}$ with $2 \times$ Mueller-Hinton (MH) broth. Ohelo berry juice was two-fold serially diluted with sterilized water to obtain 0-fold, 2-fold, 4-fold, 8-fold, 16-fold, 32-fold, and 64-fold dilutions. Then, the same volumes of $2 \times \mathrm{MH}$ broth with $6 \log \mathrm{CFU} / \mathrm{mL}$ L. monocytogenes and serially diluted ohelo berry juice were mixed to yield $50 \%, 25 \%, 12.5 \%, 6.25 \%, 3.125 \%, 1.56 \%$, or $0.78 \%$ of ohelo berry juice, and $5 \log \mathrm{CFU} / \mathrm{mL}$ of bacteria. A positive control was established to be 1:1 of sterilized water and $2 \times \mathrm{MH}$ broth with $6 \log \mathrm{CFU} / \mathrm{mL}$ of bacteria. A negative control was established by mixing sterilized water with un-inoculated $2 \times \mathrm{MH}$ broth. The cocktails were incubated at $37^{\circ} \mathrm{C}$ for $24 \mathrm{~h}$. Viable cell counts were determined at 0 and $24 \mathrm{~h}$ on plate count agar (PCA). Plates were incubated at $37^{\circ} \mathrm{C}$ for $24 \mathrm{~h}$ before enumeration. Minimum inhibitory concentration (MIC) was determined as the lowest concentration of the juice that inhibited the growth of L. monocytogenes after incubation. Minimum bactericidal concentration (MBC) was determined as the lowest concentration of the juice that killed L. monocytogenes after incubation [23]. MIC and MBC were determined by comparing viable cell counts between the control and treatments at 0 and $24 \mathrm{~h}$. The procedures were modified from the methodology described by Lacombe et al. [24], where MH broth was used in the present study. 


\subsection{Growth Inhibition Kinetics of Ohelo Berry Juice against L. monocytogenes}

The L. monocytogenes culture was 10-fold serially diluted to approximately $5 \log$ $\mathrm{CFU} / \mathrm{mL}$ with $2 \times \mathrm{MH}$ broth. The same volume of serially diluted ohelo berry juice was added to the medium to achieve final concentrations of $50 \%, 25 \%, 12.5 \%$, and $6.25 \%$. The samples were incubated at $37^{\circ} \mathrm{C}$ for $24 \mathrm{~h}$ and collected at $0,2,4,8$, and $24 \mathrm{~h}$ for plating on PCA. The plates were incubated at $37^{\circ} \mathrm{C}$ for $24 \mathrm{~h}$ before enumeration. The growth inhibition kinetic curve was prepared by plotting bacterial concentration versus time.

\subsection{Evaluation of the Physicochemical Properties and Biofilm Formation Capability of L. monocytogenes Treated with Ohelo Berry Juice \\ 2.6.1. Hydrophobicity}

Hydrophobicity was determined according to the method described by Salaheen et al. [25]. L. monocytogenes was grown in Luria-Bertani (LB) broth in the absence and presence of predetermined sub-inhibitory concentrations ( $\frac{1}{2}$ MIC and $\frac{1}{4}$ MIC) of ohelo berry juice at $37^{\circ} \mathrm{C}$ for $24 \mathrm{~h}$. Each culture was centrifuged at $3000 \mathrm{~g}$ for $20 \mathrm{~min}$. The cells were thoroughly suspended in $5 \mathrm{~mL}$ of phosphate buffer saline (PBS, pH 7.2). The absorption of suspension was measured at $570 \mathrm{~nm}$ using a spectrophotometer (UV-1600PC, VWR) and adjusted to approximately $0.5(\mathrm{Ht} 0)$ with PBS. After that, $2 \mathrm{~mL}$ of each adjusted solution was transferred to a new tube and mixed with $1 \mathrm{~mL}$ of $\mathrm{n}$-hexadecane, followed by incubation at room temperature for $5 \mathrm{~min}$. The hexadecane phase was removed, and the absorption of the aqueous phase was measured at $570 \mathrm{~nm}$ (Ht5). Hydrophobicity was calculated using the equation as follows:

$$
\text { Hydrophobicity }(\%)=(1-\mathrm{Ht} 5 / \mathrm{Ht} 0) \times 100
$$

\subsubsection{Auto-Aggregation}

L. monocytogenes cells were treated with sub-inhibitory concentrations of ohelo berry juice as described above. After the cells were collected, they were thoroughly suspended in $5 \mathrm{~mL}$ of PBS. The absorption of cell suspension was measured at $570 \mathrm{~nm}$ and adjusted to approximately 0.5 (At0) with PBS. A volume of $3 \mathrm{~mL}$ of adjusted cell solution was transferred to a new tube and incubated at $37{ }^{\circ} \mathrm{C}$ for $2 \mathrm{~h}$. After that, the absorption of the supernatant was measured at $570 \mathrm{~nm}$ (At5). Auto-aggregation was calculated by the equation below [25]:

$$
\text { Auto-aggregation }(\%)=(1-\text { At } 5 / \text { At } 0) \times 100
$$

\subsubsection{Motility}

Motility was determined via an assay described previously, with minor modifications [26]. Firstly, $0.2 \%$ and $0.5 \%$ LB agar were prepared for swimming and swarming motility tests, respectively. The lower agar density for swimming motility in the present study allowed bacteria to move within the agar easily. Two milliliters of $62.5 \%$ and $31.25 \%$ ohelo berry juice were mixed with $18 \mathrm{~mL}$ warm LB agar at around $50{ }^{\circ} \mathrm{C}$ and poured into Petri dishes, representing $6.25 \%\left(\frac{1}{2}\right.$ MIC) and $3.125 \%\left(\frac{1}{4}\right.$ MIC) of ohelo berry juice in the agar, respectively. An equal amount of water was used as a negative control. After the agar was solidified, $2 \mu \mathrm{L}$ of fresh L. monocytogenes culture was spotted in the center of the agar. The plates were incubated at $37^{\circ} \mathrm{C}$ for 24 to $48 \mathrm{~h}$. The migration of bacteria from the point of inoculation after incubation reflected their motility. The diameter of the growth zone was measured for control and the treatments.

\subsubsection{Biofilm Formation}

The procedures for this assay were modified from a method described previously [27]. Fresh L. monocytogenes culture was 10-fold diluted 4 times with $2 \times \mathrm{MH}$ broth. Aliquots $(100 \mu \mathrm{L})$ of diluted L. monocytogenes culture were transferred into wells of a sterile polystyrene, flat-bottom, 96-well plate. Then, $100 \mu \mathrm{L}$ of MIC and $\frac{1}{2}$ MIC ohelo berry juice were mixed in triplicate with bacterial cultures to a final concentration of $\frac{1}{2}$ MIC and $\frac{1}{4}$ MIC, respectively. Further, un-inoculated MH broth with the ohelo juice dilutions $(100 \mu \mathrm{L})$ was prepared 
in triplicate to serve as negative controls. The plates were incubated at $37^{\circ} \mathrm{C}$ for $48 \mathrm{~h}$, followed by decanting the broth from each well and rinsing gently three times with PBS. In the present study, the plate was allowed to dry at $75{ }^{\circ} \mathrm{C}$ for $30 \mathrm{~min}$. Then $210 \mu \mathrm{L}$ of $0.4 \%$ (wt/vol) crystal violet (CV) was added to each well, and the plate was incubated at room temperature for $15 \mathrm{~min}$. Unabsorbed CV in each well was removed, and the well was rinsed with deionized water. Subsequently, $210 \mu \mathrm{L}$ of absolute ethanol was loaded into the well to solubilize the $\mathrm{CV}$ adsorbed to the biomass, and the plate was incubated at room temperature for $10 \mathrm{~min}$. The absorbance was measured at $570 \mathrm{~nm}$ using a microplate reader (Biotek Synergy LX, BioTek Instruments, Santa Clara, CA, USA) to quantify the solubilized CV. Negative controls with cell-free broth were used to adjust for background signals.

\section{7. $R T-q P C R$}

Quantitative reverse transcription-polymerase chain reaction (RT-qPCR) was employed to quantify the expression of selected genes in L. monocytogenes treated with ohelo berry juice, using a method described by Wu et al. [28]. L. monocytogenes was grown in $\mathrm{MH}$ broth in the absence and presence of $\frac{1}{2}$ MIC and $\frac{1}{4}$ MIC of ohelo berry juice at $37^{\circ} \mathrm{C}$ for $24 \mathrm{~h}$. Then, $450 \mu \mathrm{L}$ of each culture was transferred to a $1.7 \mathrm{~mL}$ microcentrifuge tube for RNA extraction using RNeasy Mini Kit (Qiagen, Hilden, Germany), following the manufacturer's instructions. Concentrations of RNA extracts were measured using Nanophotometer PClass 300 (Implen, Munich, Germany) and adjusted for further purification with RQ1 DNase (Promega, Madison, WI, USA) to remove DNA contamination. The concentrations of digested RNA were measured again and reverse-transcribed using the High-Capacity cDNA Reverse Transcription Kit (Applied Biosystems, Waltham, MA, USA). Briefly, $5 \mu \mathrm{g}$ of digested RNA was mixed with $10 \mu \mathrm{L}$ of $2 \times \mathrm{RT}$ master mix and nuclease-free $\mathrm{H}_{2} \mathrm{O}$ to a total volume of $20 \mu \mathrm{L}$. The synthesis reaction was performed in the MJ Mini Thermal Cycler (Bio-Rad, Hercules, CA, USA) at $25^{\circ} \mathrm{C}$ for $10 \mathrm{~min}, 37^{\circ} \mathrm{C}$ for $120 \mathrm{~min}$, and $85^{\circ} \mathrm{C}$ for $5 \mathrm{~min}$. The cDNA samples were stored at $-20^{\circ} \mathrm{C}$. Quantitative PCR was performed using GoTaq qPCR Master Mix (Promega) as follows: $1 \mu \mathrm{L}$ cDNA, $1 \mu \mathrm{L}$ of forward primer $(50 \mu \mathrm{M}), 1 \mu \mathrm{L}$ of reverse primer $(50 \mu \mathrm{M}), 10 \mu \mathrm{L}$ of $2 \times$ GoTaq qPCR Master Mix, and $7 \mu \mathrm{L}$ of Nuclease-free $\mathrm{H}_{2} \mathrm{O}$. The amplification was performed in CFX96 Real-Time Detection Systems (Bio-Rad), and the thermal cycling parameters were set with an initial denaturation at $95^{\circ} \mathrm{C}$ for $2 \mathrm{~min}$, followed by 40 cycles of denaturation at $95^{\circ} \mathrm{C}$ for $15 \mathrm{~s}$, annealing at $60{ }^{\circ} \mathrm{C}$ for $1 \mathrm{~min}$, and extension at $72{ }^{\circ} \mathrm{C}$ for $1 \mathrm{~min}$. Information about the primers used in quantitative PCR is shown in Table 1. The relative expression levels of genes were calculated by the comparative method using CFX Maestro ${ }^{\mathrm{TM}}$ Software (Bio-Rad) [29]. The housekeeping gene, 16S $r R N A$, was used as the reference gene for the normalization of the target gene expression [30]. 
Table 1. Information about the primers used in Quantitative PCR.

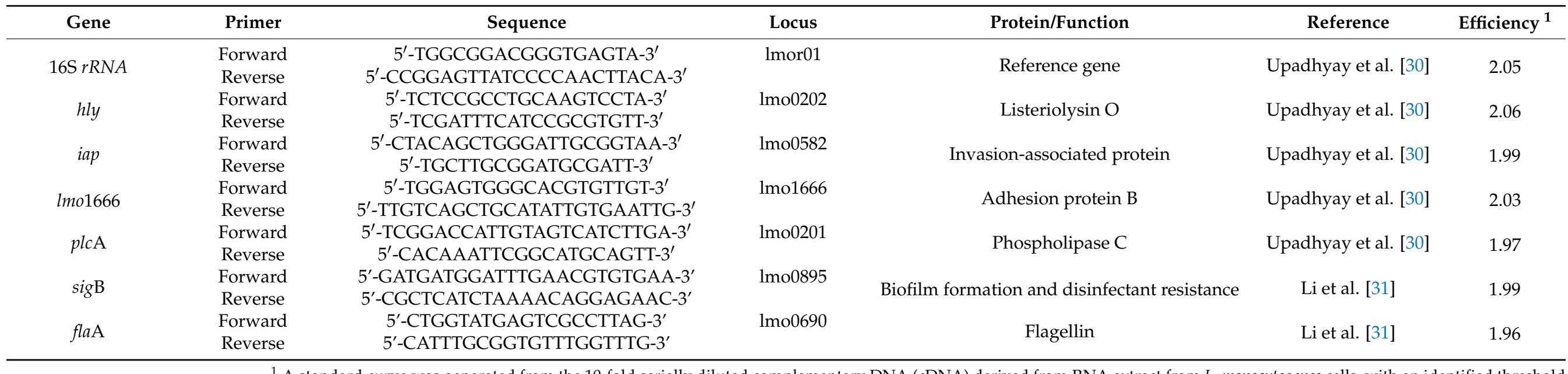

${ }^{1}$ A standard curve was generated from the 10-fold serially diluted complementary DNA (cDNA) derived from RNA extract from L. monocytogenes cells, with an identified threshold cycle number $(\mathrm{C} t)$ and slope of the trend line. The efficiency was calculated using the equation: $\mathrm{E}=-1+10^{\wedge}(-1 /$ slope) [28]. 


\subsection{Effect of Ohelo Berry Juice on the Growth of L. monocytogenes in Milk}

The effectiveness of ohelo berry juice on suppressing the growth of L. monocytogenes in milk was investigated. Ultra-high-temperature whole milk and skim milk were purchased from a local supermarket. The L. monocytogenes culture was 10-fold serially diluted with peptone water $(0.1 \%)$, and $0.1 \mathrm{~mL}$ of bacterial dilutions was added into $10 \mathrm{~mL}$ of milk containing $12.5 \%$ (MIC), 25\% (2 MIC), and 50\% (MBC) ohelo berry juice to achieve a bacterial concentration of $6 \log \mathrm{CFU} / \mathrm{mL}$. Inoculated milk $(10 \mathrm{~mL})$ without ohelo berry juice was included as a positive control. The milk samples were incubated at 7 or $37^{\circ} \mathrm{C}$ for $72 \mathrm{~h}$. Aliquots were removed at $0,6,24,48$, and $72 \mathrm{~h}$ for the bacterial count. An agar overlay method was employed to recover injured bacterial cells [32]. Briefly,10-fold serial dilutions of the samples were spread on PCA. The plates were incubated at $37^{\circ} \mathrm{C}$ for $2 \mathrm{~h}$ for the resuscitation of injured cells. After the 2-h preincubation, $10 \mathrm{~mL}$ of melted modified Oxford Agar supplemented with Moxalactam Supplement (Sigma-Aldrich) were poured onto PCA, allowed to solidify, and incubated at $37^{\circ} \mathrm{C}$ for $48 \mathrm{~h}$. Colonies of a brown color surrounded by a black zone were recorded as L. monocytogenes.

\subsection{Statistical Analysis}

All experiments were performed in three independent replicates. The viable cell counts of L. monocytogenes were converted to $\log \mathrm{CFU} / \mathrm{mL}$, and means and standard deviations were calculated by using Microsoft Excel (Version 2201). The physicochemical properties, biofilm formation capability, and gene expression patterns of $L$. monocytogenes treated with different concentrations of ohelo berry juice were compared. The data were analyzed by analysis of variance (ANOVA) and Tukey's multiple comparison test to determine significant differences between treatments and storage time at $p<0.05$ using Statistical Packages Multcomp [33] and Agricolae [34] in RStudio version 3.6.2 (Rstudio, Boston, MA, USA).

\section{Results}

\subsection{Chemical Analysis of Ohelo Berry Juice}

Aside from acidity, phenolic compounds (especially anthocyanins) may play a considerable role in the antibacterial activity of cranberry $[11,12,15]$. Thus, the $\mathrm{pH}$ value, sugar and organic acids, total phenolics, and anthocyanin contents of ohelo berry juice were measured. Ohelo berry juice had quite a low pH of 3.27 (Table 2). The sugar and titratable acidity in ohelo berry juice was measured at a ratio of 7.6/1.42 Bx/acid. Total phenolics and anthocyanins were analyzed by the Folin Ciocalteu method and the $\mathrm{pH}$ differential method, respectively. The results showed the concentrations of total phenolics and anthocyanins in ohelo berry juice were $4.2 \mathrm{mg} / \mathrm{mL}$ GAE and $55.11 \mathrm{mg} / \mathrm{L}$ cyd-3-glu, respectively.

Table 2. The $\mathrm{pH}$ values of diluted ohelo berry juice.

\begin{tabular}{cc}
\hline Concentration & pH \\
\hline $100 \%$ & $3.27 \pm 0.03 \mathrm{a}^{1}$ \\
\hline $50 \%$ & $3.86 \pm 0.04 \mathrm{~b}$ \\
\hline $25 \%$ & $4.24 \pm 0.02 \mathrm{c}$ \\
\hline $12.5 \%$ & $4.69 \pm 0.04 \mathrm{~d}$ \\
\hline $6.25 \%$ & $5.40 \pm 0.01 \mathrm{e}$ \\
\hline $3.12 \%$ & $6.37 \pm 0.02 \mathrm{f}$ \\
\hline $1.56 \%$ & $6.85 \pm 0.05 \mathrm{~g}$ \\
\hline $0.78 \%$ & $7.09 \pm 0.01 \mathrm{~h}$ \\
\hline
\end{tabular}

${ }^{1}$ Means with different letters (a through $\mathrm{h}$ ) are significantly different at $p<0.05$. 


\subsection{Antimicrobial Effect of Ohelo Berry Juice on L. monocytogenes}

Ohelo berry juice was added into MH broth to determine its MIC and MBC against L. monocytogenes. With dilution, the $\mathrm{pH}$ of ohelo berry juice gradually increased from 3.86 at $50 \%$ to 7.09 at $0.78 \%$ (Table 2). Meanwhile, the antimicrobial activity of ohelo berry juice became weaker. As shown in Figure 1, each dilution of the juice was assessed for viable cell count at $24 \mathrm{~h}$, compared with the initial level at $0 \mathrm{~h}$ and the cell count of the control at $24 \mathrm{~h}$. No significant difference was observed in the bacterial growth after 24-h incubation when $12.5 \%$ ohelo berry juice was added. Moreover, L. monocytogenes was non-detectable after 24-h incubation with 50\% ohelo berry juice. Therefore, the MIC and MBC of ohelo berry juice against $L$. monocytogenes were $12.5 \%$ and $50 \%$, respectively. Based on these results, the growth inhibition kinetics of the juice at concentrations of $50 \%, 25 \%, 12.5 \%$, and $6.25 \%$ were assessed against L. monocytogenes. Figure 2 illustrates the behavior of the bacteria in diluted ohelo berry juice treatments within $24 \mathrm{~h}$. Ohelo berry juice slowly killed the bacteria at an initial concentration of about $5.2 \log \mathrm{CFU} / \mathrm{mL}$. The level of L. monocytogenes decreased by $1.46 \log$ in the $50 \%$ juice treatment from 0 to $8 \mathrm{~h}$, and the bacteria was completely inactivated by $24 \mathrm{~h}$. When L. monocytogenes was exposed to the MIC of ohelo berry juice in MH broth, the number of bacteria almost remained stable for the entire $24 \mathrm{~h}$.

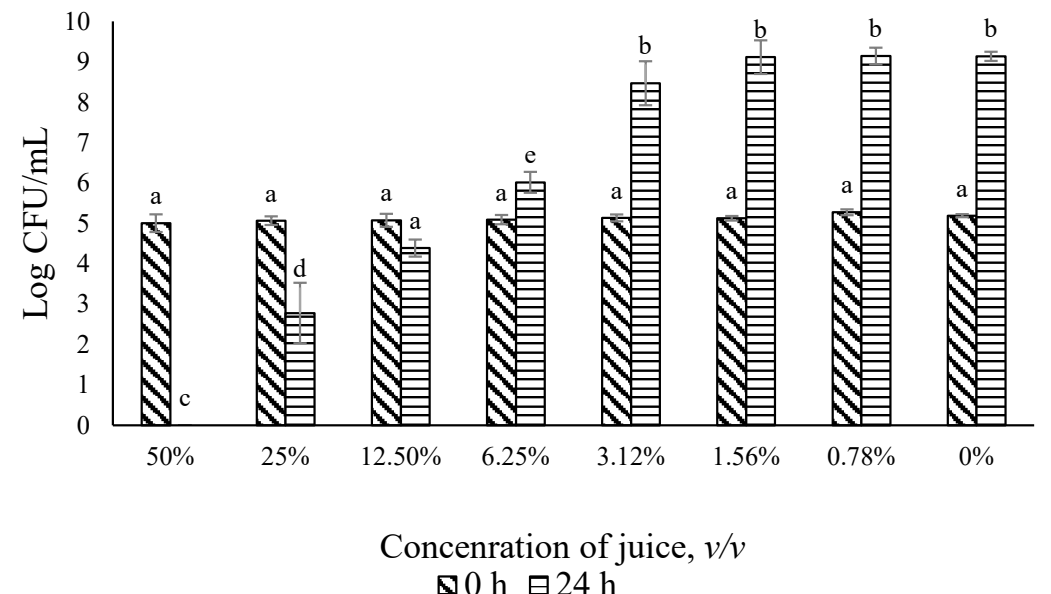

Figure 1. Evaluation of the antimicrobial effect of ohelo berry juice on Listeria monocytogenes. The viable cell counts of diluted ohelo berry juice in Mueller-Hinton broth were determined at 0 and $24 \mathrm{~h}$. Means with different letters (a through e) are significantly different at $p<0.05$.

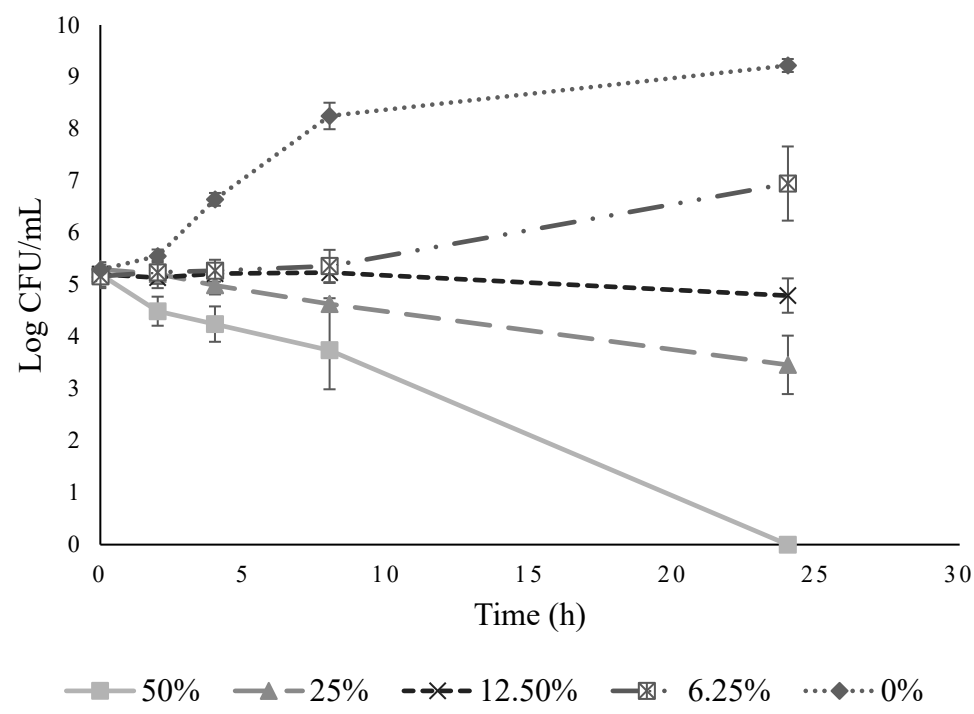

Figure 2. Growth inhibition kinetics of diluted ohelo berry juice (50\%, 25\%, $12.5 \%$, and $6.25 \%$ ) and control ( $0 \%$ ) against Listeria monocytogenes in Mueller-Hinton broth. 
3.3. Effect of Ohelo Berry Juice on the Physicochemical Properties and Biofilm Formation Capability of L. monocytogenes

Ohelo berry juice showed a significant effect on tested physicochemical properties and biofilm formation capability of L. monocytogenes in microbiological media (Table 3). After being exposed to sub-inhibitory concentrations of the juice in LB broth for $24 \mathrm{~h}$, L. monocytogenes decreased significantly $(p<0.05)$ in its cell surface hydrophobicity, which was $2.77 \%$ and $2.14 \%$ in the presence of $3.12 \%\left(\frac{1}{4} \mathrm{MIC}\right)$ and $6.25 \%$ ( $\left.\frac{1}{2} \mathrm{MIC}\right)$ ohelo berry juice, respectively, compared to $7.71 \%$ in the control (Table 3 ). In contrast, the auto-aggregation capability of L. monocytogenes cells significantly increased from $16.02 \%$ in the control to $67.98 \%$ in the $6.25 \%$ ohelo berry juice treatment (Table 3 ). In soft LB agar without ohelo berry juice, L. monocytogenes formed large migration zones, reflecting its strong motility. However, cells were only able to form colonies in the center of agar plates with the juice. The bacterial swimming motility decreased significantly from $100 \%$ in the control to $41.29 \%$ and $4.39 \%$ with $3.12 \%$ and $6.25 \%$ ohelo berry juice, respectively. Similarly, both juice treatments resulted in significantly lower swarming motility of L. monocytogenes than the control. Finally, ohelo berry juice helped prevent biofilm formation of L. monocytogenes on polystyrene plates. Biofilm formation capability of L. monocytogenes in $\mathrm{MH}$ broth decreased significantly by $45.67 \%$ and $77 \%$ m with $3.12 \%$ and $6.25 \%$ ohelo berry juice, respectively (Table 3 ).

Table 3. Physicochemical properties and biofilm formation capability of L. monocytogenes in the presence of ohelo berry juice ${ }^{1}$.

\begin{tabular}{cccccc}
\hline $\begin{array}{c}\text { Ohelo Berry Juice } \\
\mathbf{( \% )}\end{array}$ & $\begin{array}{c}\text { Hydrophobicity } \\
\mathbf{( \% )}\end{array}$ & $\begin{array}{c}\text { Auto-Aggregation } \\
\mathbf{( \% )}\end{array}$ & $\begin{array}{c}\text { Swimming } \\
\left.\text { Motility } \mathbf{~}_{\mathbf{\%}}\right)\end{array}$ & $\begin{array}{c}\text { Swarming } \\
\text { Motility }^{\mathbf{2}} \mathbf{( \% )}\end{array}$ & $\begin{array}{c}\text { Biofilm } \\
\text { Formation } \mathbf{~}^{\mathbf{( \% )}}\end{array}$ \\
\hline 0 & $7.71 \pm 0.85 \mathrm{a}$ & $16.02 \pm 2.83 \mathrm{a}$ & $100 \mathrm{a}$ & $100 \mathrm{a}$ & $100 \mathrm{a}$ \\
\hline 3.12 & $2.77 \pm 0.46 \mathrm{~b}$ & $23.95 \pm 3.83 \mathrm{a}$ & $41.29 \pm 3.00 \mathrm{~b}$ & $22.80 \pm 0.31 \mathrm{~b}$ & $54.33 \pm 0.39 \mathrm{~b}$ \\
\hline 6.25 & $2.14 \pm 0.87 \mathrm{~b}$ & $67.98 \pm 10.92 \mathrm{~b}$ & $4.39 \pm 0.17 \mathrm{c}$ & $14.71 \pm 0.23 \mathrm{~b}$ & $23.00 \pm 0.53 \mathrm{c}$ \\
\hline
\end{tabular}

${ }^{1}$ Means with different letters in the same column (a through c) are significantly different at $p<0.05 .{ }^{2}$ Motility and biofilm formation values were normalized to untreated control.

\subsection{Effect of Ohelo Berry Juice on Gene Expression of L. monocytogenes}

Quantitative RT-PCR was performed to determine the effect of ohelo berry juice on the transcription of six genes in L. monocytogenes, with the 16S rRNA gene as an internal reference gene. The quantitative PCR efficiency for the $16 \mathrm{~S} r R N A, h l y$, iap, lmo1666, plcA, $\operatorname{sig} \mathrm{B}$, and fla $\mathrm{A}$ gene was within an acceptable range of 1.96 to 2.06 (Table 1). Relative expression of these genes was corrected for efficiency. Compared with the control, 6.25\% ohelo berry juice significantly down-regulated all target genes but $1 m 01666$. A significant reduction in transcript abundance was also observed for hly and plcA in L. monocytogenes treated with the $3.12 \%$ juice. In contrast, neither $6.25 \%$ nor $3.12 \%$ ohelo berry juice showed any significant effect on the expression of $l m o 1666$ (Figure 3). 


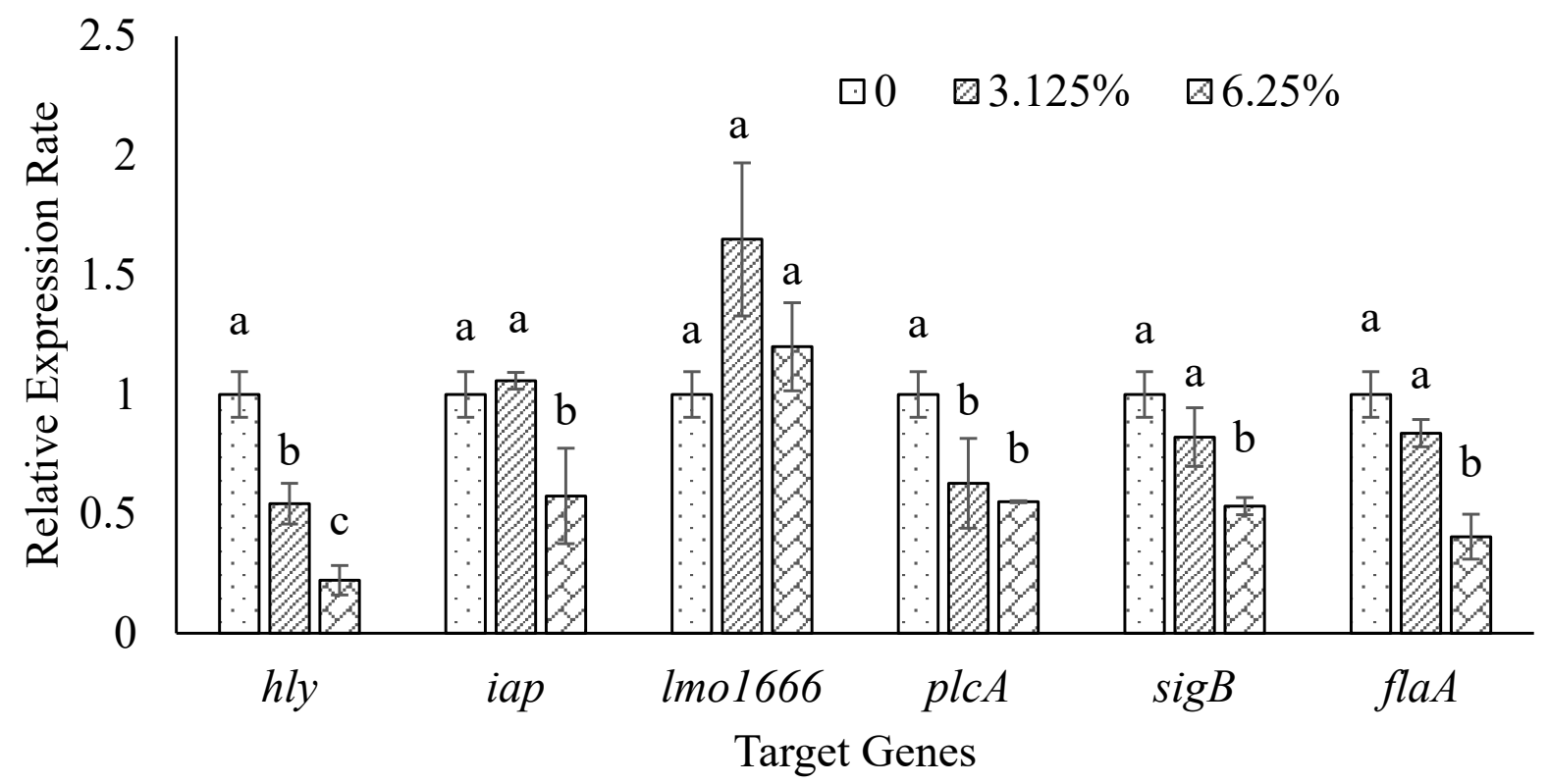

Figure 3. Relative expression levels of selected genes in L. monocytogenes after treatment with $6.25 \%$, $3.12 \%$, or no ohelo berry juice. Bars labeled with different letters indicate significant differences between the means of treatments at $p<0.05$.

\subsection{Effect of Ohelo Berry Juice on the Growth of L. monocytogenes in Milk}

The antimicrobial properties of ohelo berry juice were evaluated in whole milk and skim milk stored at 7 and $37^{\circ} \mathrm{C}$ for $72 \mathrm{~h}$ (Figure 4). L. monocytogenes populations in whole milk stored at $37^{\circ} \mathrm{C}$ increased from an initial level of $6.31 \pm 0.05 \log$ to $8.14 \pm 0.31 \log$ $\mathrm{CFU} / \mathrm{mL}$ after $6 \mathrm{~h}$ and remained at around $8.5 \log \mathrm{CFU} / \mathrm{mL}$ through the $72-\mathrm{h}$ incubation (Figure $4 \mathrm{~A}$ ). The addition of ohelo berry juice to whole milk at $12.5 \%$ (MIC) showed no significant difference from control. When the concentration of juice increased to $25 \%$ $(2 \times \mathrm{MIC})$, a significant inhibitory effect on $L$. monocytogenes was observed at $6 \mathrm{~h}$, with the bacterial count being $7.25 \pm 0.25 \log \mathrm{CFU} / \mathrm{mL}$. However, L. monocytogenes overcame the inhibitory effect and reached a level $(8.37 \pm 0.17 \log \mathrm{CFU} / \mathrm{mL})$ similar to the control at $24 \mathrm{~h}$. In contrast, treatment with $50 \%$ (MBC) ohelo berry juice exhibited antimicrobial activities in a time-dependent manner and significantly reduced the number of L. monocytogenes in whole milk to $4.21 \pm 0.18 \log \mathrm{CFU} / \mathrm{mL}$ at $72 \mathrm{~h}$ (Figure $4 \mathrm{~A}$ ).

Consistently, the addition of $50 \%$ ohelo berry juice to whole milk stored at $7^{\circ} \mathrm{C}$ resulted in the significant inhibition of L. monocytogenes through a storage period of $72 \mathrm{~h}$ with mean counts similar to the initial level $(6.10 \pm 0.17 \log \mathrm{CFU} / \mathrm{mL})$ (Figure 4B). The count of L. monocytogenes in whole milk without juice was $6.22 \pm 0.06 \log \mathrm{CFU} / \mathrm{mL}$ at $0 \mathrm{~h}$, then slowly reached $7.44 \pm 0.09 \log \mathrm{CFU} / \mathrm{mL}$ at $72 \mathrm{~h}$. The $12.5 \%$ juice in whole milk at $7{ }^{\circ} \mathrm{C}$ did not limit the growth of bacteria when compared to control at any time point during incubation, whereas $25 \%$ juice in whole milk resulted in a significantly lower bacterial population compared with the control at $48 \mathrm{~h}$ and $72 \mathrm{~h}$ (Figure $4 \mathrm{~B}$ ).

The growth of L. monocytogenes in skim milk incubated at $37^{\circ} \mathrm{C}$ was similar to the observation in whole milk (Figure 4C). In the absence of ohelo berry juice, the count of L. monocytogenes increased from $6.18 \pm 0.09 \log$ to $8.08 \pm 0.18 \log \mathrm{CFU} / \mathrm{mL}$ at $6 \mathrm{~h}$ and remained at approximately $8.6 \log \mathrm{CFU} / \mathrm{mL}$. Only the treatment with $50 \%$ juice exhibited significant inhibition of L. monocytogenes over time, with a mean count of $5.02 \pm 0.09 \mathrm{log}$ $\mathrm{CFU} / \mathrm{mL}$ at $72 \mathrm{~h}$. Neither $12.5 \%$ nor $25 \%$ treatment showed an antimicrobial effect on L. monocytogenes in skim milk at $37^{\circ} \mathrm{C}$ (Figure $4 \mathrm{C}$ ). 


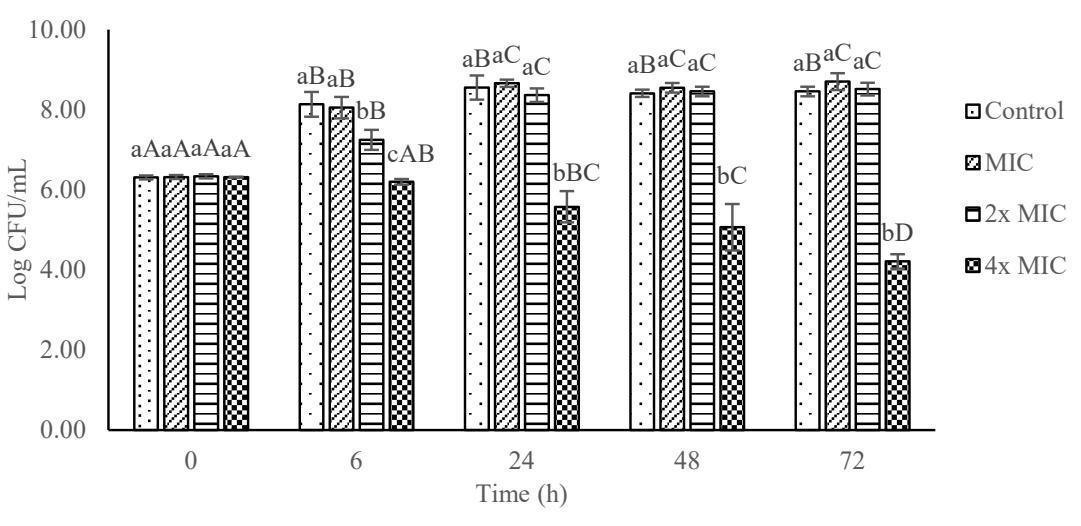

(a)

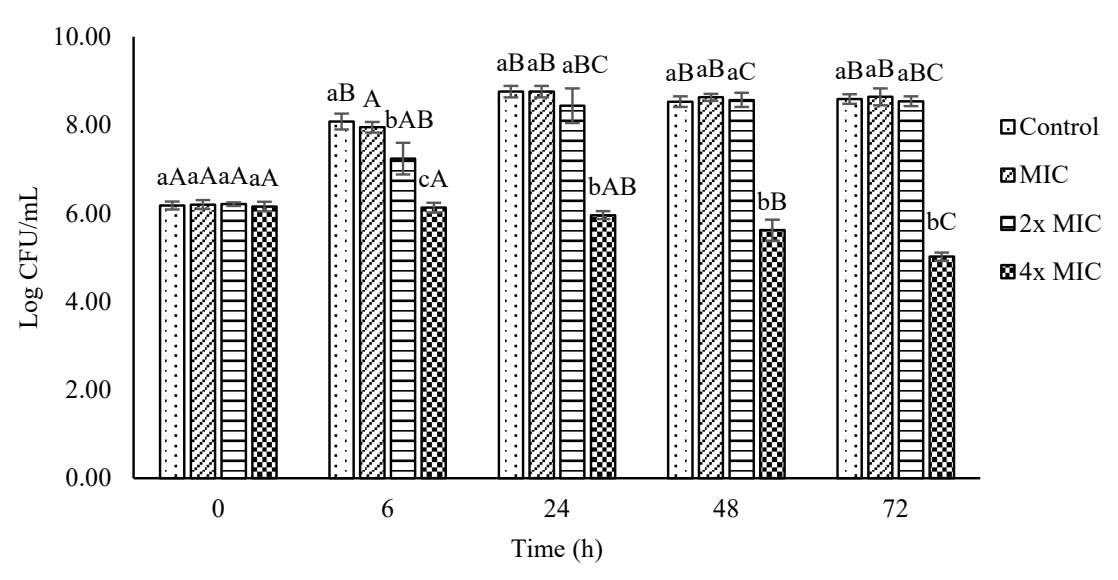

(c)

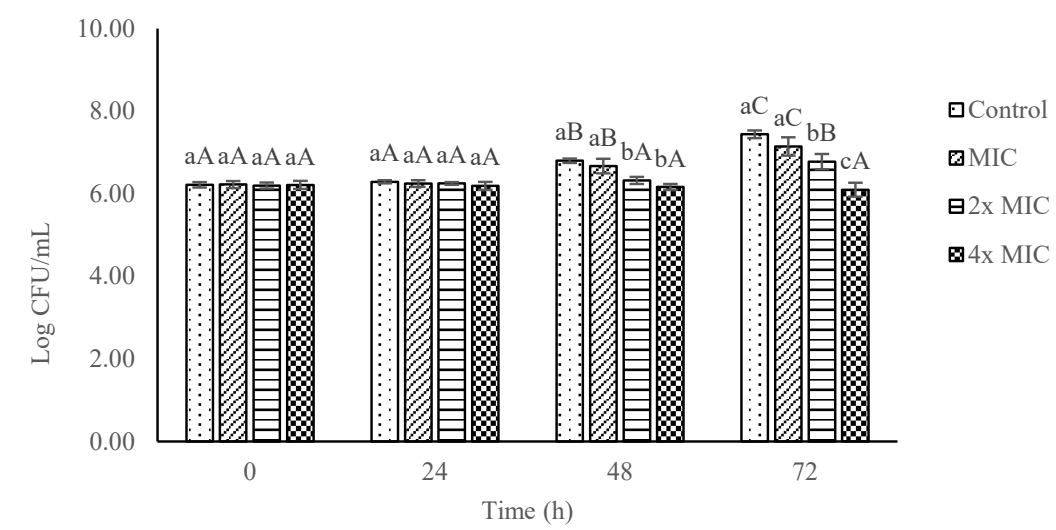

(b)

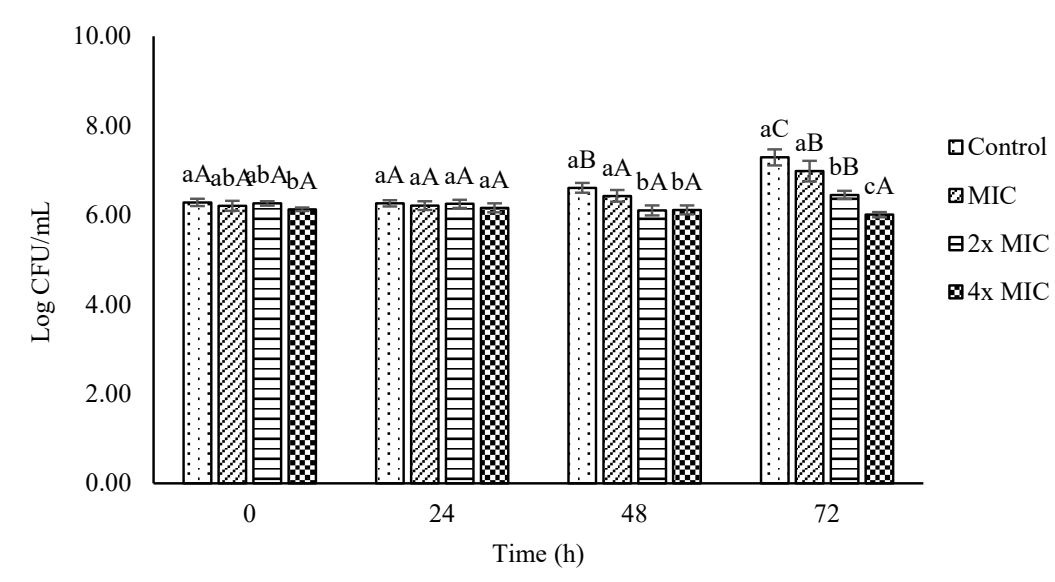

(d)

Figure 4. Effect of ohelo berry juice at concentrations of $12.5 \%$ (MIC), $25 \%(2 \times \mathrm{MIC})$, and $50 \%(4 \times \mathrm{MIC})$ on the growth of L. monocytogenes in whole milk at $37^{\circ} \mathrm{C}(\mathrm{a})$, whole milk at $7{ }^{\circ} \mathrm{C}(\mathbf{b})$, skim milk at $37^{\circ} \mathrm{C}(\mathbf{c})$, and skim milk at $7{ }^{\circ} \mathrm{C}(\mathrm{d})$ for $72 \mathrm{~h}$. Within each time point, means with different lowercase letters are significantly different $(p<0.05)$ between the treatments. Within each treatment, means with different capital letters are significantly different $(p<0.05)$ between the time points. 
Similar to those of whole milk treatments (Figure 4B), bacterial counts of skim milk with $12.5 \%$ ohelo berry juice incubated at $7{ }^{\circ} \mathrm{C}$ did not differ from control through $72-\mathrm{h}$ storage (Figure 4D). Nevertheless, counts of skim milk with $25 \%$ juice were significantly lower than control at 48 and $72 \mathrm{~h}$. When the concentration of ohelo berry juice increased to $50 \%$, the antimicrobial effect was significantly stronger than all other treatments at $72 \mathrm{~h}$ (Figure 4D). The results suggest that ohelo berry juice could effectively inhibit the growth of L. monocytogenes in milk regardless of the fat content and could potentially be used as an antimicrobial agent as well as a natural flavoring in dairy beverages.

\section{Discussion}

In the dairy industry, it is critical to minimize the risk of L. monocytogenes, which is mainly associated with unpasteurized or minimally processed milk and post-pasteurization contamination from plant environments [35]. Antimicrobial interventions using natural food preservatives have garnered increasing attention in order to enhance the safety of these products.

Cranberry is rich in antioxidants and polyphenolics that have strong antimicrobial activities and other health benefits $[8,15,36]$. As a Hawaiian wild relative of cranberry, ohelo berry has comparable or even higher phenolic contents than cranberry [18]. In this study, the total phenolics and anthocyanins in ohelo berry juice were $4.2 \mathrm{mg} / \mathrm{mL}$ GAE and $55.11 \mathrm{mg} / \mathrm{L}$ cyd-3-glu, respectively. According to previous reports, the total phenolic content of cranberry juice varied from 0.5 to $2 \mathrm{mg} / \mathrm{mL}$ GAE $[8,37,38]$. The anthocyanins in cranberry juice were in a range of 0.9 to $1.4 \mathrm{mg} / 100 \mathrm{~mL}$ cyd-3-glu and depends on quantification methods $[21,39]$. Ohelo berry juice has a $\mathrm{pH}$ of 3.27 , higher than that of cranberry juice (2.70) [18]. The sugar and titratable acidity ratio of ohelo berry juice was 7.6/1.42 Bx/acid, which was comparable to the results of the phytochemical composition analysis of ohelo berry juice previously [18]. It is also noteworthy that cranberry and ohelo berry have different phenolic compositions and anthocyanin profiles [18], implying their distinct antimicrobial potential.

The MIC and MBC of ohelo berry juice against L. monocytogenes were determined to be $12.5 \%$ and $50 \%$, respectively (Figure 1 ). The $\mathrm{pH}$ of $12.5 \%$ ohelo berry juice was 4.69 (Table 2), higher than the minimum growth $\mathrm{pH}$ (4.4) of L. monocytogenes [31]. This suggests that the antimicrobial property of ohelo berry juice may be attributed to both organic acids and other bioactive compounds. Malic, citric, shikimic, and quinic acids are present in ohelo berry [18]. Being protonated, organic acids can cross the cell membrane into bacterial cytoplasm. Adenosine $5^{\prime}$-triphosphate (ATP) is required to pump the protons released from the acids out of the cell. Therefore, the lack of ATP may lead to the inhibition of bacterial growth [36].

Since Côté et al. reported that neutralized cranberry juice still maintained its antimicrobial effect on seven bacterial strains [8], the phenolics in ohelo berry, similar to those in cranberry, may act against bacteria through various modes of action, including protein precipitation, enzyme inactivation, membrane disruption, and leakage of cellular contents [13]. Specifically, anthocyanins, a type of polyphenolic flavonoid, can inhibit bacteria by damaging cell membranes and affecting enzymatic activities [13]. In addition, the tricarboxylic acid (TCA) cycle and the biosynthesis of bacterial cells may be affected by anthocyanins [13]. L. monocytogenes is a gram-positive bacteria and has thick peptidoglycan cell walls, which are prone to damage by polyphenols [40]. Moreover, polyphenols may sequester free ions, which are essential for the survival and virulence of bacteria [41]. Thus, the antimicrobial activity of ohelo berry may be a result of a synergy between its organic acid and phenolic contents.

Biofilm is a complex surface attachment community composed of various microorganisms, which are held together by extracellular polymer substances they produce [42]. About $60 \%$ of foodborne illness outbreaks and $80 \%$ of bacterial infections are related to biofilms [43]. L. monocytogenes biofilms formed in food processing environments are resistant to sanitizers and hard to eradicate, which poses a serious food safety concern. 
Dushku et al. [44] reported that the biofilm formation capability of L. monocytogenes was associated with cell surface properties, such as hydrophobicity and auto-aggregation, which were essential for its increased tolerance to gut barriers, survival in the host, and hypervirulence activity. Hydrophobicity influences bacterial adhesion, proliferation, and distribution. Fan et al. [45] reported that L. monocytogenes strains with higher hydrophobicity exhibited stronger adhesion and biofilm-forming capacity. Choi et al. [46] also showed that biofilm formation of L. monocytogenes was positively correlated with its hydrophobicity level. The present study demonstrated that sub-inhibitory concentrations of ohelo berry juice could significantly decrease the hydrophobicity and biofilm formation capability of L. monocytogenes in a concentration-dependent manner. Moreover, changes in bacterial hydrophobicity may alter surface tensions between bacterial cells and result in a tendency of bacterial cells to attach to each other and form aggregates $[47,48]$. Interestingly, the present study revealed that $6.25 \%$ ohelo berry juice indeed increased the auto-aggregation of L. monocytogenes, while the biofilm formation of L. monocytogenes was inhibited with reducing hydrophobicity (Table 3). In contrast, Kim et al. [49] found that the cell-free supernatant of probiotic Saccharomyces cerevisiae could inhibit the biofilm formation of L. monocytogenes along with decreasing auto-aggregation and hydrophobicity. Nevertheless, Choi et al. [46] reported that the hydrophobicity and auto-aggregation capability of L. monocytogenes might be two independent traits, though both were necessary for adhesion. Wang et al. [48] investigated the effects of extracts from cranberry on five L. monocytogenes strains isolated from raw chicken with respect to their hydrophobicity and auto-aggregation. They reported that significant increases of hydrophobicity and auto-aggregation of L. monocytogenes ATCC 7644 were observed in the presence of cranberry, though a significant increase of hydrophobicity along with a significant decrease of auto-aggregation was found for cranberry-treated L. monocytogenes B2. The results showed that the changes of hydrophobicity and autoaggregation were dependent on the type of L. monocytogenes strains.

Motility is another important property of bacteria that plays a crucial role in initial attachment and the spread of bacteria on a surface for subsequent biofilm formation [26,50]. The swimming motility refers to the flagella-directed movement in aqueous environments, whereas swarming motility is the flagella-directed rapid movement on solid surfaces [26]. Dons et al. [51] showed that the swarming motility of L. monocytogenes was critical in initial contact with epithelial cells and contributed to the effective invasion of host cells. Our study revealed that sub-inhibitory concentrations of ohelo berry juice could significantly decrease the swarming and swimming motility of L. monocytogenes, highlighting the promise of ohelo berry as a potential agent to suppress the movement of L. monocytogenes and sequentially reduce the infection.

To further understand the antimicrobial property of ohelo berry juice, expression patterns of six genes in treated L. monocytogenes cells were examined. The target genes included hly, iap, plcA, lmo1666, sigB, and flaA (Table 1). The flaA gene and sig B gene play an important role in the motility and biofilm formation of cells [31]. Down-regulation of these two genes by $6.25 \%$ ohelo berry juice might inhibit the motility and biofilm formation of L. monocytogenes (Figure 3), in agreement with physicochemical property and biofilm formation tests (Table 3). However, the juice treatments did not significantly affect the expression of the lmo1666 gene (Figure 3), which encodes Listeria adhesion protein B [30]. Adhesion is an important step in biofilm formation [31]. Reduced biofilm formation of L. monocytogenes by sub-inhibitory concentrations of ohelo berry juice could be due to the down-regulation of other adhesion-related genes in L. monocytogenes, such as 1 mo1634 and lmo1847 [30]. Finally, the iap gene encodes a protein responsible for the invasion of host cells by L. monocytogenes [30]. The hly gene codes for listeriolysin O, which enables L. monocytogenes cells to escape phagosome and cause infection [52]. The plcA gene encodes phosphatidylinositol phospholipase C [53]. The down-regulated expression of these three genes suggested that ohelo berry juice could prevent $L$. monotytogenes infection by inhibiting the production of virulence factors by L. monocytogenes (Figure 3). 
Milk was used as a model to examine the antimicrobial property of ohelo berry juice in food matrices. It is conceivable that the effectiveness of antimicrobials would be weakened in food than in broth media because of possible interactions of antimicrobials with food components, inactivation by enzymatic modification, poor solubility, and uneven distribution $[2,54,55]$. The present study showed that L. monocytogenes in milk increased in $72 \mathrm{~h}$ from $6 \log$ to 7.3 and $8.5 \log \mathrm{CFU} / \mathrm{mL}$ at 7 and $37^{\circ} \mathrm{C}$, respectively (Figure 4). Complete elimination of L. monocytogenes was not achieved with the tested concentrations of ohelo berry juice in our study, but cell counts of L. monocytogenes were significantly reduced by 1 to $2 \log \mathrm{CFU} / \mathrm{mL}$ in milk supplemented with $50 \%$ ohelo berry juice at $37^{\circ} \mathrm{C}$ for $72 \mathrm{~h}$. Furthermore, the $50 \%$ juice exhibited bacteriostatic effects on L. monocytogenes in milk throughout incubation at $7{ }^{\circ} \mathrm{C}$. Similar observations were reported by Biswas et al. [56], who investigated the effectiveness of blueberry juice mixed with skim milk $(1: 1)$ on the growth of L. monocytogenes. They found that the counts of $L$. monocytogenes were reduced by about $1.5 \log \mathrm{CFU} / \mathrm{mL}$ after a $72-\mathrm{h}$ incubation at $37^{\circ} \mathrm{C}$. Additionally, Yang et al. [55] concluded that the growth of L. monocytogenes was inhibited in both whole and skim milk supplemented with $10 \%$ blackberry juice stored at $37^{\circ} \mathrm{C}$ for $72 \mathrm{~h}$. No significant difference was observed between whole milk and skim milk. Similarly, $50 \%$ ohelo berry juice proved to be effective in reducing the number of L. monocytogenes in both whole and skim milk, revealing that the fat content of milk did not interfere with the interaction of bioactive compounds in ohelo berry juice with bacterial cells. In contrast, the antimicrobial properties of nisin and glycolipids against $L$. monocytogenes in milk were significantly reduced by its fat content $[57,58]$.

\section{Conclusions}

This study showed the ohelo berry juice exerted effective antimicrobial activities against $L$. monocytogenes. Sublethal concentrations of ohelo berry juice significantly increased auto-aggregation and decreased hydrophobicity, swimming motility, swarming motility, and biofilm formation capability of L. monocytogenes, highlighting potential applications of ohelo berry juice to tackling hygienic and sanitary issues in the food industry. Furthermore, the expression of motility, biofilm formation, and virulence-related genes in L. monocytogenes was down-regulated by the juice treatments. L. monocytogenes was significantly inhibited in whole and skim milk supplemented with $50 \%$ ohelo berry juice regardless of fat content, underlining the potential of ohelo berry as a natural food preservative to control foodborne pathogens in milk products. This is the first report on the antimicrobial property of ohelo berry. It is worth further exploring the application of ohelo berry in broad food matrices, such as unpasteurized cheese, and its influence on the sensory and nutritional properties of ohelo berry-supplemented products.

Author Contributions: Conceptualization, S.T.N. and Y.L.; methodology, B.W., X.L. and Y.L.; investigation, B.W. and X.L.; formal analysis, B.W., X.L. and Y.L.; resources, S.T.N. and Y.L.; writing-original draft preparation, B.W. and X.L.; writing-review and editing, B.W., X.L., S.T.N., M.W. and Y.L.; funding, S.T.N., M.W. and Y.L.; supervision, Y.L. All authors have read and agreed to the published version of the manuscript.

Funding: This work was supported by the USDA-National Institute of Food and Agriculture Hatch Grants HAW02024-H and HAW02033-H, the United States Department of Agriculture-Agricultural Research Service Agreement No. 58-2040-8-010, and the Hawaii State Department of Agriculture, Specialty Crops Block Grant Contract No. 65476.

Institutional Review Board Statement: Not applicable.

Informed Consent Statement: Not applicable. 
Data Availability Statement: Not applicable.

Acknowledgments: The authors thank Joanne Lichty Imamura for harvesting and storing the ohelo berries used in this study.

Conflicts of Interest: The authors have no competing financial interests or personal relationships that could have influenced this study.

\section{References}

1. Centers for Disease Control and Prevention. Listeria (Listeriosis). Centers for Disease Control and Prevention. Available online: https:/ / www.cdc.gov / listeria/risk.html (accessed on 27 May 2021).

2. Chen, H.; Zhong, Q. Lactobionic acid enhances the synergistic effect of nisin and thymol against Listeria monocytogenes Scott A in tryptic soy broth and milk. Int. J. Food Microbiol. 2017, 260, 36-41. [CrossRef] [PubMed]

3. Cossart, P.; Bierne, H. The use of host cell machinery in the pathogenesis of Listeria monocytogenes. Curr. Opin. Immunol. 2001, 13, 96-103. [CrossRef]

4. Interagency Food Safety Analytics Collaboration (IFSAC). Foodborne Illness Source Attribution Estimates for 2019 for Salmonella, Escherichia Coli O157, Listeria Monocytogenes and Campylobacter Using Multi-Year Outbreak Surveillance Data, United States; GA and D.C. U.S. Department of Health and Human Services' Centers for Disease Control and Prevention and U.S. Food and Drug Administration, U.S. Department of Agriculture's Food Safety and Inspection Service: Atlanta, GA, USA, 2021. Available online: https:/ / www.cdc.gov/foodsafety/ifsac/annual-reports.html (accessed on 29 January 2022).

5. Das, Q.; Islam, M.R.; Marcone, M.F.; Warriner, K.; Diarra, M.S. Potential of berry extracts to control foodborne pathogens. Food Control 2017, 73, 650-662. [CrossRef]

6. Okocha, R.C.; Olatoye, I.O.; Adedeji, O.B. Food safety impacts of antimicrobial use and their residues in aquaculture. Public Health Rev. 2018, 39, 21. [CrossRef]

7. Dellavalle, C.T.; Daniel, C.R.; Aschebrook-Kilfoy, B.; Hollenbeck, A.R.; Cross, A.J.; Sinha, R.; Ward, M.H. Dietary intake of nitrate and nitrite and risk of renal cell carcinoma in the NIH-AARP Diet and Health Study. Br. J. Cancer 2013, 108, 205-212. [CrossRef]

8. Baenas, N.; Ruales, J.; Moreno, D.A.; Barrio, D.A.; Stinco, C.M.; Martínez-Cifuentes, G.; Meléndez-Martínez, A.J.; García-Ruiz, A. Characterization of Andean Blueberry in Bioactive Compounds, Evaluation of Biological Properties, and in vitro Bioaccessibility. Foods 2020, 9, 1483. [CrossRef]

9. Lacombe, A.; McGivney, C.; Tadepalli, S.; Sun, X.; Wu, V.C. The effect of American cranberry (Vaccinium macrocarpon) constituents on the growth inhibition, membrane integrity, and injury of Escherichia coli O157:H7 and Listeria monocytogenes in comparison to Lactobacillus rhamnosus. Food Microbiol. 2013, 34, 352-359. [CrossRef]

10. Lau, A.T.Y.; Barbut, S.; Ross, K.; Diarra, M.S.; Balamurugan, S. The effect of cranberry pomace ethanol extract on the growth of meat starter cultures, Escherichia coli O157: H7, Salmonella enterica serovar Enteritidis and Listeria monocytogenes. LWT 2019, 115, 108452. [CrossRef]

11. Sun, X.H.; Zhou, T.T.; Wei, C.H.; Lan, W.Q.; Zhao, Y.; Pan, Y.J.; Wu, V.C. Antibacterial effect and mechanism of anthocyanin rich Chinese wild blueberry extract on various foodborne pathogens. Food Control 2018, 94, 155-161. [CrossRef]

12. Côté, J.; Caillet, S.; Doyon, G.; Dussault, D.; Sylvain, J.F.; Lacroix, M. Antimicrobial effect of cranberry juice and extracts. Food Control 2011, 22, 1413-1418. [CrossRef]

13. Zhao, Y.; Jiang, Q. Roles of the polyphenol-gut microbiota interaction in alleviating colitis and preventing colitis-associated colorectal cancer. Adv. Nutr. 2021, 12, 546-565. [CrossRef] [PubMed]

14. Vinson, J.A.; Su, X.; Zubik, L.; Bose, P. Phenol antioxidant quantity and quality in foods: Fruits. J. Agric. Food Chem. 2001, 49, 5315-5321. [CrossRef] [PubMed]

15. Alshaibani, D.; Zhang, R.; Wu, V.C. Antibacterial characteristics and activity of Vaccinium macrocarpon proanthocyanidins against diarrheagenic Escherichia coli. J. Funct. Foods 2017, 39, 133-138. [CrossRef]

16. Degener, O. Plants of Hawaii National Park Illustrative of Plants and Customs of the South Seas; Food and Agriculture Organization of the United Nations: Rome, Italy; Braun-Brumfield, Inc.: Ann Arbor, MI, USA, 1973; pp. 240-245.

17. Zee, F.; Keith, L.; Follett, P.; Bassil, N.; Reed, B.; Strauss, A.; Arakawa, C.; Kawabata, A.; Hamasaki, R.; Nakamoto, S.T.; et al. Kìlauea and Red Button: Two 'Ōhelo, Vaccinium Reticulatum, Cultivars from Hawai' $i$; College of Tropical Agriculture and Human Resources, University of Hawai'i at Mānoa: Honolulu, Hawaii, 2011; Available online: https://www.ctahr.hawaii.edu/oc/ freepubs/pdf/F_N-18.pdf (accessed on 29 January 2022).

18. Hummer, K.; Durst, R.; Zee, F.; Atnip, A.; Giusti, M.M. Phytochemicals in fruits of Hawaiian wild cranberry relatives. J. Sci. Food Agric. 2014, 94, 1530-1536. [CrossRef]

19. Hong, V.; Wrolstad, R.E. Cranberry juice composition. J. Assoc. Off. Anal. Chem. 1986, 69, 199-207. [CrossRef]

20. Wrolstad, R.E.; Acree, T.E.; Decker, E.A.; Penner, M.H.; Reid, D.S.; Schwartz, S.J.; Shoemaker, C.F.; Smith, D.M.; Sporns, P. Handbook of Food Analytical Chemistry, Volume 2: Pigments, Colorants, Flavors, Texture, and Bioactive Food Components; John Wiley \& Sons: Hoboken, NJ, USA, 2005; pp. 457-537.

21. Lee, J.; Durst, R.W.; Wrolstad, R.E. Determination of total monomeric anthocyanin pigment content of fruit juices, beverages, natural colorants, and wines by the $\mathrm{pH}$ differential method: Collaborative study. J. AOAC Int. 2005, 88, 1269-1278. [CrossRef] 
22. Clinical and Laboratory Standards Institute. Methods for Dilution Antimicrobial Susceptibility Tests for Bacteria that Grow Aerobically. Approved Standard -Eighth Edition; CLSI publication M07-A8; Clinical and Laboratory Standards Institute: Wayne, PA, USA, 2009; Available online: https:/ /simpleshowoflove.weebly.com/uploads/1/4/0/7/14073276/agar_dilution_assay.pdf (accessed on 29 January 2022).

23. Andrews, J.M. Determination of minimum inhibitory concentrations. J. Antimicrob. Chemother. 2001, 48 (Suppl. 1), 5-16. [CrossRef]

24. Lacombe, A.; Wu, V.C.; White, J.; Tadepalli, S.; Andre, E.E. The antimicrobial properties of the lowbush blueberry (Vaccinium angustifolium) fractional components against foodborne pathogens and the conservation of probiotic Lactobacillus rhamnosus. Food Microbiol. 2012, 30, 124-131. [CrossRef]

25. Salaheen, S.; Nguyen, C.; Hewes, D.; Biswas, D. Cheap extraction of antibacterial compounds of berry pomace and their mode of action against the pathogen Campylobacter jejuni. Food Control 2014, 46, 174-181. [CrossRef]

26. O'May, C.; Tufenkji, N. The swarming motility of Pseudomonas aeruginosa is blocked by cranberry proanthocyanidins and other tannin-containing materials. Appl. Environ. Microbiol. 2011, 77, 3061-3067. [CrossRef]

27. O'Toole, G.A. Microtiter dish biofilm formation assay. J. Vis. Exp. JoVE 2011, 47, 2437. [CrossRef]

28. Wu, V.C.; Qiu, X.; de los Reyes, B.G.; Lin, C.S.; Pan, Y. Application of cranberry concentrate (Vaccinium macrocarpon) to control Escherichia coli O157:H7 in ground beef and its antimicrobial mechanism related to the downregulated slp, hdeA and cfa. Food Microbiol. 2009, 26, 32-38. [CrossRef]

29. Pfaffl, M.W. A new mathematical model for relative quantification in real-time RT-PCR. Nucleic Acids Res. 2001, 29, e45. [CrossRef]

30. Upadhyay, A.; Johny, A.K.; Amalaradjou, M.A.; Baskaran, S.A.; Kim, K.S.; Venkitanarayanan, K. Plant-derived antimicrobials reduce Listeria monocytogenes virulence factors in vitro, and down-regulate expression of virulence genes. Int. J. Food Microbiol. 2012, 157, 88-94. [CrossRef]

31. Li, J.; Li, S.; Li, H.; Guo, X.; Guo, D.; Yang, Y.; Wang, X.; Zhang, C.; Shan, Z.; Xia, X.; et al. Antibiofilm activity of shikonin against Listeria monocytogenes and inhibition of key virulence factors. Food Control 2021, 120, 107558. [CrossRef]

32. Yan, Z.; Gurtler, J.B.; Kornacki, J.L. A solid agar overlay method for recovery of heat-injured Listeria monocytogenes. J. Food Prot. 2006, 69, 428-431. [CrossRef]

33. Hothorn, T.; Bretz, F.; Westfall, P. Simultaneous Inference in General Parametric Models. Biom. J. 2008, 50, 346-363. [CrossRef] [PubMed]

34. De Mendiburu, F.; Yaseen, M. Agricolae: Statistical Procedures for Agricultural Research.R Package Version 1.4.0; 2020. Available online: https:/ / myaseen208.github.io/agricolae/https:/ / cran.r-project.org/package=agricolae (accessed on 21 January 2022).

35. Lee, S.H.I.; Cappato, L.P.; Guimarães, J.T.; Balthazar, C.F.; Rocha, R.S.; Franco, L.T.; da Cruz, A.G.; Corassin, C.H.; de Oliveira, C.A.F. Listeria monocytogenes in milk: Occurrence and recent advances in methods for inactivation. Beverages 2019, 5, 14. [CrossRef]

36. Lima, M.C.; de Sousa, C.P.; Fernandez-Prada, C.; Harel, J.; Dubreuil, J.D.; de Souza, E.L. A review of the current evidence of fruit phenolic compounds as potential antimicrobials against pathogenic bacteria. Microb. Pathog. 2019, 130, 259-270. [CrossRef] [PubMed]

37. Pedersen, C.B.; Kyle, J.; Jenkinson, A.M.; Gardner, P.T.; McPhail, D.B.; Duthie, G.G. Effects of blueberry and cranberry juice consumption on the plasma antioxidant capacity of healthy female volunteers. Eur. J. Clin. Nutr. 2000, 54, 405-408. [CrossRef]

38. Vinson, J.A.; Bose, P.; Proch, J.; Al Kharrat, H.; Samman, N. Cranberries and cranberry products: Powerful in vitro, ex vivo, and in vivo sources of antioxidants. J. Agric. Food Chem. 2008, 56, 5884-5891. [CrossRef]

39. Lee, J.; Rennaker, C.; Wrolstad, R.E. Correlation of two anthocyanin quantification methods: HPLC and spectrophotometric methods. Food Chem. 2008, 110, 782-786. [CrossRef]

40. Nohynek, L.J.; Alakomi, H.L.; Kähkönen, M.P.; Heinonen, M.; Helander, I.M.; Oksman-Caldentey, K.M.; Puupponen-Pimiä, R.H. Berry phenolics: Antimicrobial properties and mechanisms of action against severe human pathogens. Nutr. Cancer 2006, 54, 18-32. [CrossRef] [PubMed]

41. Guo, M.; Perez, C.; Wei, Y.; Rapoza, E.; Su, G.; Bou-Abdallah, F.; Chasteen, N.D. Iron-binding properties of plant phenolics and cranberry's bio-effects. Dalton Trans. 2007, 43, 4951-4961. [CrossRef] [PubMed]

42. Muhammad, M.H.; Idris, A.L.; Fan, X.; Guo, Y.; Yu, Y.; Jin, X.; Qiu, J.; Guan, X.; Huang, T. Beyond risk: Bacterial biofilms and their regulating approaches. Front. Microbiol. 2020, 11, 928. [CrossRef] [PubMed]

43. Han, Q.; Song, X.; Zhang, Z.; Fu, J.; Wang, X.; Malakar, P.K.; Liu, H.; Pan, Y.; Zhao, Y. Removal of foodborne pathogen biofilms by acidic electrolyzed water. Front. Microbiol. 2017, 8, 988. [CrossRef] [PubMed]

44. Dushku, E.; Kotzamanidis, C.; Avgousti, K.; Zdragas, A.; Vafeas, G.; Giantzi, V.; Staikou, A.; Yiangou, M. Listeria monocytogenes induced dysbiosis in snails and rebiosis achieved by administration of the gut commensal Lactobacillus plantarum Sgs14 strain. Fish Shellfish. Immunol. 2020, 104, 337-346. [CrossRef] [PubMed]

45. Fan, Y.; Qiao, J.; Lu, Z.; Fen, Z.; Tao, Y.; Lv, F.; Zhao, H.; Zhang, C.; Bie, X. Influence of different factors on biofilm formation of Listeria monocytogenes and the regulation of cheY gene. Food Res. Int. 2020, 137, 109405. [CrossRef]

46. Choi, N.Y.; Bae, Y.M.; Lee, S.Y. Cell surface properties and biofilm formation of pathogenic bacteria. Food Sci. Biotechnol. 2015, 24 2257-2264. [CrossRef]

47. Trunk, T.; Khalil, H.S.; Leo, J.C. Bacterial autoaggregation. AIMS Microbiol. 2018, 4, 140-164. [CrossRef]

48. Wang, Y.; Baptist, J.A.; Dykes, G.A. Garcinia mangostana extract inhibits the attachment of chicken isolates of Listeria monocytogenes to cultured colorectal cells potentially due to a high proanthocyanidin content. J. Food Saf. 2021, 41, e12889. [CrossRef] 
49. Kim, Y.J.; Yu, H.H.; Song, Y.J.; Park, Y.J.; Lee, N.K.; Paik, H.D. Anti-biofilm effect of the cell-free supernatant of probiotic Saccharomyces cerevisiae against Listeria monocytogenes. Food Control 2021, 121, 107667. [CrossRef]

50. Lemon, K.P.; Higgins, D.E.; Kolter, R. Flagellar motility is critical for Listeria monocytogenes biofilm formation. J. Bacteriol. 2007, 189, 4418-4424. [CrossRef] [PubMed]

51. Dons, L.; Eriksson, E.; Jin, Y.; Rottenberg, M.E.; Kristensson, K.; Larsen, C.N.; Bresciani, J.; Olsen, J.E. Role of flagellin and the two-component CheA/CheY system of Listeria monocytogenes in host cell invasion and virulence. Infect. Immun. 2004, 72, 3237-3244. [CrossRef]

52. Hamon, M.A.; Ribet, D.; Stavru, F.; Cossart, P. Listeriolysin O: The Swiss army knife of Listeria. Trends Microbiol. 2012, 20, 360-368. [CrossRef] [PubMed]

53. Hadjilouka, A.; Molfeta, C.; Panagiotopoulou, O.; Paramithiotis, S.; Mataragas, M.; Drosinos, E.H. Expression of Listeria monocytogenes key virulence genes during growth in liquid medium, on rocket and melon at 4, 10 and $30 \mathrm{C}$. Food Microbiol. 2016, 55, 7-15. [CrossRef] [PubMed]

54. Hartmann, H.A.; Wilke, T.; Erdmann, R. Efficacy of bacteriocin-containing cell-free culture supernatants from lactic acid bacteria to control Listeria monocytogenes in food. Int. J. Food Microbiol. 2011, 146, 192-199. [CrossRef] [PubMed]

55. Yang, H.; Hewes, D.; Salaheen, S.; Federman, C.; Biswas, D. Effects of blackberry juice on growth inhibition of foodborne pathogens and growth promotion of Lactobacillus. Food Control 2014, 37, 15-20. [CrossRef]

56. Biswas, D.; Wideman, N.E.; O’Bryan, C.A.; Muthaiyan, A.; Lingbeck, J.M.; Crandall, P.G.; Ricke, S.C. Pasteurized blueberry (Vaccinium corymbosum) juice inhibits growth of bacterial pathogens in milk but allows survival of probiotic bacteria. J. Food Saf. 2012, 32, 204-209. [CrossRef]

57. Jung, D.S.; Bodyfelt, F.W.; Daeschel, M.A. Influence of fat and emulsifiers on the efficacy of nisin in inhibiting Listeria monocytogenes in fluid milk. J. Dairy Sci. 1992, 75, 387-393. [CrossRef]

58. Sun, L.; Forauer, E.C.; Brown, S.; D'Amico, D.J. Application of bioactive glycolipids to control Listeria monocytogenes biofilms and as post-lethality contaminants in milk and cheese. Food Microbiol. 2021, 95, 103683. [CrossRef] [PubMed] 